\title{
Adorno on Hope
}

In this paper I argue that Theodor W. Adorno's philosophy articulates a radical conception of hope. This may come as a surprise to readers who associate Adorno with some of his bleakest pronouncements on the state of human civilization and its future prospects. After all, he is notorious for his claims that 'all post-Auschwitz culture...is garbage' ( $N D$ 359/367), and that while there is no direct line from savagery to humanitarianism, there is one from the slingshot to the megaton bomb (ND 314/320). These claims have given rise to a bourgeoning literature on Adorno's conception of progress (Allen 2016), but commentators have paid comparatively little attention to his conception of hope. ${ }^{1} \mathrm{I}$ argue that this is unfortunate for two reasons. First, if Adorno's philosophy is to serve the anticipatory-utopian as well as the explanatorydiagnostic function of critical social theory (Benhabib 1996: 226, Allen 2016), then it must articulate a conception of hope in order to justify why hope rather than despair is the appropriate response to the devastating state of the world that it has diagnosed. Thus, my argument in this paper, if successful, will make a contribution to understanding the critical purchase of Adorno's philosophy. Second, Adorno's conception of hope is of wider interest for philosophical discussions of hope, because it occupies a distinct position in the conceptual landscape. It shares important features with one of the most prominent conceptions of hope, articulated in Jonathan Lear's book, Radical Hope (2006), while differing from it in at least one important respect. While Lear's conception of radical hope is about a future that is radically different from the past, it depends on the continued affirmation of the meaning and value of the past. In contrast, for Adorno, the Holocaust has thrown the meaning and value of our past into radical doubt, and so his conception of radical hope must do without any positive appeal to our past. Thus, it may serve as a useful alternative for philosophers who are 
attracted to Lear's conception of radical hope but troubled by its dependence on the affirmation of the past. $^{2}$

I begin my argument with a brief discussion of Lear's conception of radical hope and an initial sketch how Adorno's conception of it differs from Lear's (§1). Next, I turn to Adorno's criticism of Kant's conception of hope, because Adorno develops his conception of hope through a critique of Kantian hope. I argue that Kant has a specific conception of hope that differs from both ordinary and radical hope through its rational constraints. Adorno believes that these constraints of Kantian hope can no longer be met and, therefore, only a radical conception of hope can be defended (§2). However, Adorno’s own experience shows that hope is not entirely voluntary and potentially dangerous, if it tips over into a positive picture of a better, future world $(\S 3)$. In particular, there is a regressive metaphysical need to believe in such a better, future world, but Adorno argues that the right response to this danger is to have the courage to know the worst (§4). Only then genuine hope will follow. Finally, I briefly look at two reasons for hope that can be found in Adorno’ work (§5).

\section{Negativism and Radical Hope}

Lear introduces the concept of radical hope in order to make sense of the comportment of the Crow Chief Plenty Coups as he led his tribe through a period of cultural devastation. During his lifetime, Plenty Coups experienced the end of the Crow way of life, which revolved around hunting and warfare. When the Crow had to stop hunting Buffalo, move onto a reservation and cease warfare, they lost not only the material basis of their way of life, but also the entire horizon of meaning and value that had informed their life, their poetry, and their rituals. Lear shows how Plenty Coups responded to this cultural devastation with great 
courage, making creative decisions, such as leading his tribe into a pact with the American forces against the Sioux, negotiating with Washington politicians and achieving good outcomes for the Crow in a difficult political environment. Plenty Coup's courage was underpinned by radical hope that the Crow would flourish again, a hope that he traced back to a childhood dream (I will return to this dream below).

What, then, is radical hope? According to Lear, '[w]hat makes...hope radical is that it is directed toward a future goodness that transcends the current ability to understand what it is. Radical hope anticipates a good for which those who have the hope as yet lack the appropriate concepts with which to understand it' (Lear 2006: 103). Elsewhere in the book, Lear writes that it is a commitment to the 'bare idea' or 'possibility...that something good will emerge (Lear 2006: 94, 97). If ordinary hope is the desire for a good outcome that is neither certain nor impossible, but whose goodness is well understood by the person who desires $i^{3}$, radical hope is the desire for an outcome where the ground of its desirability, that is, its goodness, transcends the current abilities of those who desire it to understand what it is. It is a desire for a future that therefore can only be grasped as good retrospectively, if and when it has eventuated and equipped people with concepts with which they can understand it (Lear 2006: 115).

It is easy to see why Adorno's conception of hope must share important features with Lear's conception of radical hope. According to most interpretations, Adorno's critical social theory is negativistic. As Fabian Freyenhagen has argued, this negativism takes four forms (Freyenhagen 2013: 3-5, 2017: 862). First, Adorno is an epistemic negativist who believes that we currently cannot know what the good is or what happiness is. Second, this epistemic negativism means that Adorno must be a methodological negativist; he thinks that 
philosophers should investigate negative phenomena, such as pain and suffering, rather than positive ones, such as the good or happiness, in order to elaborate their theories. Third, more specifically, Freyenhagen argues that Adorno, therefore, should be read as a meta-ethical negativist who accounts for the normative force of his ethics through an appeal to what is bad for human beings, rather than through an appeal to what is good for them or what makes them happy (Freyenhagen 2013: chapters 7-9). Finally, and most controversially, Freyenhagen argues that Adorno subscribes to epistemic negativism (and therefore to methodological and meta-ethical negativism), because he is a substantive negativist who believes that the modern world is bad or, as he often puts it, radically evil, rather than good. Substantive negativism is controversial, because it seems to imply that the world does not contain anything positive, all things considered. Any seeming goodness or happiness is either fleeting or tainted by its entanglements in the radically evil world (Freyenhagen 2013: 10-11, 2017: 870; cf. Theunissen 1983: 47).

To be sure, one may doubt the plausibility of substantive negativism, and it is not entirely clear what status it has in Adorno's critical social theory. If it is meant to be a factual claim, it is hard to see how it could be demonstrated. How could one show that, as a matter of fact, no genuine goodness or happiness does exist in the current social world? If it is a normative judgment about the current social world, people may reasonably disagree whether the evil that undoubtedly exists or has existed (for example, during the Holocaust), in fact, does taint all goodness and happiness in the present, or whether there are 'features of our lives...that are not falsely meaningful' (and, presumably, good), for example in personal relationships (O'Connor 2017: 858). Of course, even if one doubts the plausibility of substantive negativism, one still may endorse epistemic negativism and remain agnostic about the existence of genuine goodness or happiness, because the radical evil that pervades the current 
social world makes it impossible to know whether any genuine goodness or happiness exists or to identify it reliably. As we shall see, much of Adorno's argument does not depend on substantive negativism, but it does make a difference when it comes to understanding why Adorno thinks that we have reasons for hope (see my discussion in $\S 5$ below).

In addition, Adorno's reflections on hope reveal that he endorses a fifth form of negativism. He is an imaginative negativist who thinks that we cannot conceive or imagine what the good would look like. Imaginative negativism is a distinct form of negativism and more radical than epistemic negativism, because imagining is not constrained by the epistemic norms of knowledge acquisition, and, therefore, we reasonably can imagine much more than we can know. However, there is clear evidence that Adorno denies our ability to imagine the good. Thus, in one well-known passage, he writes: 'In the right condition everything would be, as in the Jewish theologoumenon, only the slightest bit different from what it is now, but not the slightest thing can be imagined [vorstellen] about how it would then be' (ND 294/352). Similarly, discussing the 'supremacy' of objective reality in determining what we can think, he writes:

Whoever presents an image of the right conditions, in order to answer the objection that he does not know what he wants, cannot disregard that supremacy [which extends] also over him. Even if his imagination [Phantasie] were capable of imagining [vorzustellen] everything as radically different, it would still remain chained to him and his present time as static points of reference, and everything would be askew. (ND 345/35)

Like epistemic negativism, one can endorse imaginative negativism without endorsing substantive negativism, because the radically evil world taints our imagination. ${ }^{4}$ 
While Plenty Coups' radical hope is a response to the end of the traditional Crow way of life, the historical background of Adorno's discussion of negativism is the Holocaust, although his methodological negativism may precede it. Adorno sees the Holocaust as the culmination of the realisation of evil in the world, after which nothing can remain as it was before, and everything, including philosophy, must be questioned as to its compatibility or even complicity with the bad. Adorno certainly thought that he was writing in the face of cultural devastation as much as Plenty Coups was, albeit for different reasons. Whereas the Crow Chief faced a future that would no longer contain the Crow way of life, Adorno and his contemporaries faced a future in which they no longer could appeal to the idea of human progress or the belief in the ultimate goodness of existence.

This difference between the two cases points to a very important difference between the two conceptions of radical hope. While Plenty Coup faced a future that would be radically different from his past, he was not forced to question the very meaning and value of the Crow past. Crow history up to then had not been rendered meaningless or valueless in virtue of the fact that the Crow way of life would come to an end. In fact, Lear's speculative reconstruction of Plenty Coups' thought sees his hope as being rooted in a deep commitment to the existence of a transcendent goodness in the world that makes it possible to hope for a 'revival' of the traditional Crow way of life, albeit in a form that is not yet intelligible (Lear 2006: 95). To see this, recall that the immediate source of Plenty Coups' radical hope was a childhood dream, which plays an important role in Crow mythology. Following a ritual that many young Crow underwent, Plenty Coups elicited this dream during a lonely fast in a remote place, after chopping off a fingertip and pleading with God to pity him (Lear 2006: 66). This establishes a continuity between the past and the unknown future ahead, which is 
underpinned by faith and tradition, even though neither faith nor tradition can give Plenty Coups any direct guidance on how to face the unknown future. ${ }^{5}$

In contrast, for Adorno, the Holocaust has thrown the meaning and value of our past into radical doubt. Reason itself has lost any semblance of innocence, and therefore we cannot appeal to it in any straightforward way in order to orient ourselves in our attitudes to either the past or the future. In particular, Adorno and Horkheimer's genealogy of reason in Dialectic of Enlightenment aimed to show that the rise of instrumental reason rendered the natural world meaningless while shedding the normative content of reason itself. From the standpoint of the present, the disenchanted world that resulted from this process offers neither meaningful resources that can help us to imagine a better future nor robust values that would enable us to judge what such a future ought to be like. ${ }^{6}$ This analysis gives Adorno a different reason from Plenty Coups' for why any hope for the future must be radical hope. His epistemic and imaginative negativism about the good with its roots in the experience of the Holocaust leads Adorno to argue that any determinate picture of the future will be informed by the badness of the current world and therefore tainted.

This background enables us to understand an otherwise puzzling claim that Adorno makes in the Introduction to Negative Dialectics. He writes: 'It is always the possible (das Mögliche), never the immediately actual (das unmittelbar Wirkliche), that blocks the path to utopia...' $\left(N D\right.$ 66/57). ${ }^{7}$ One way of interpreting this claim is to note that the immediately actual and utopia do not share the same conceptual space, whereas the possible and utopia do. ${ }^{8}$ Utopia, for Adorno, refers to a possible future that radically and totally differs from the past and present. As he put it in a conversation with Ernst Bloch: 
Whatever utopia is, whatever can be imagined as utopia, this is the transformation of the totality. And the imagination of such a transformation of the totality is basically very different in all the so-called utopian accomplishments [viz. those made possible by technological progress; TJ] - which, incidentally, are all really like you say: very modest, very narrow. It seems to me that what people have lost subjectively in regard to consciousness is very simply the capability to imagine the totality as something that could be completely different. (Quoted in Bloch 1987: 3-4)

Utopia is a future in which the forces of domination that characterise our radically evil world no longer blight human practices from cognition to social relations ${ }^{9}$, but it reflects the determinate negation of existing domination and evil and does not issue in the depiction of a positive future (Bloch 1987: 12). In contrast, 'the possible' refers to a possible future that we can imagine, name or depict in the here and now as a concrete possible future. However, given Adorno's commitment to epistemic and imaginative negativism, according to which no future good is knowable or imaginable, any possible future that we can imagine and name as a concrete possible future may be tainted by the badness of the actual world. This also constrains our ability to reliably imagine possible futures that would be radically different from ours, that is, no longer characterised by the forces of domination that characterise our actual world. ${ }^{10}$ For Adorno, hope that clings to the possible in this, more determinate sense, ordinary rather than radical hope, serves ideological purposes. It portrays a seemingly utopian future with the conceptual and imaginative resources of the bad world and, therefore, blocks the path to a genuine utopia. For example, in the 'Meditations on Metaphysics' Adorno writes

The idea of a fullness of life, including those which socialist conceptions hold out to human beings, is not the utopia for which it mistakes itself, because that fullness is 
inseparable from greed, from what the Jugendstil called 'living life to the full', a demand that implies violence and subjugation. (ND 371/378)

If we imagine the socialist utopia as a state in which people can fulfil their wanton desires, try out everything, and never suffer, we succumb to a primitive picture of the good that doesn't question the character of our desires or what a truly fulfilled life would be like. Like the theological Bilderverbot, to which Adorno frequently refers (e.g. ND 207/207), negative dialectics eschews concrete images of utopia in order to avoid ideological traps. All that is left is radical hope, which does not depend on such concrete images of the good, and therefore is hope for a genuine utopia.

\section{Adorno's Criticism of Kantian Hope}

In Negative Dialectics, Adorno develops his conception of radical hope through a critique of Kant's conception of hope. According to Adorno, Kant's critical philosophy is guided by a 'rescuing urge [Begierde des Rettens]' (ND 378/385), that is, the urge to rescue or salvage the achievements of dogmatic metaphysics in a non-dogmatic way. These achievements include the objectivity of experience as well as the 'cardinal propositions of metaphysics', freedom of

the will, the existence of God, and the immortality of the soul. ${ }^{11}$ Adorno offers a characterisation of Kant's predicament with regard to metaphysics that gives it a timediagnostic thrust.

Kant's rescue of the intelligible sphere is not merely the Protestant apologetics known to all; it also attempts to intervene in the dialectic of enlightenment at the point where it terminates in the abolition of reason itself. The construction of immortality as a Postulate of Pure Practical Reason bears witness to the fact that Kant's rescuing urge 
lies much deeper than simply in the pious wish to preserve something of the traditional ideas amidst nominalism and against it. It condemns the intolerability of the existing [world] and strengthens the spirit that recognises it. That no inner-worldly improvement suffices to do justice to the dead; that none touches on the unjustness of death, moves Kantian reason to hope against reason. The secret of his philosophy is the unthinkability of despair. (ND 377-78/385)

The 'dialectic of enlightenment' describes a process of disenchantment that is philosophical and social at once. The critique of reason determines the limits of reason's legitimate use. According to Adorno (and Horkheimer), this critique leaves the object domain of theoretical reason, that is, nature, disenchanted or meaningless at the same time as scientific progress enables humanity to control nature to an unprecedented degree. The limits of reason are twofold: on the one hand, human knowledge does not extend to things in themselves; on the other hand, it does not extend beyond the realm of possible experience. ${ }^{12}$ As the result, increasing success in the domination of nature coincides with a decrease in the possibilities of metaphysical experience, including the possibilities of religious faith, because the critique of reason leaves it with a realm of pure immanence that offers no conceptual space for such transcendent experience. In this context, Kant 'intervenes' in the dialectic of enlightenment with his famous declaration that he 'had to deny knowledge in order to make room for faith' (Bxxx). His 'rescue of the intelligible sphere' and the Postulates of Pure Practical Reason are the results of this intervention.

I believe that Adorno is sympathetic to the position in which Kant finds himself, but he criticises the manner in which Kant tries to extricate himself from it. ${ }^{13}$ In particular, Adorno criticises Kant for postulating God's existence and the immortality of the soul as Postulates 
of Pure Practical Reason, because these Postulates 'populate' the intelligible sphere with concrete transcendent possibilities, which have to be affirmed in thought. This move establishes Kantian hope as a third form of hope between ordinary and radical hope. As we shall see, Kantian hope differs from ordinary hope in that its rationality depends on our belief in transcendent objects. However, Kantian hope also differs from radical hope in that it gives content to an intelligible sphere, rather than limiting itself to a bare commitment to the possibility of transcendence.

At this point, it is important to spell out exactly the relationship between the Postulates of Pure Practical Reason and Kantian hope, because it is easy to miss both the distinction between moral belief and hope and the way in which the former makes the latter possible. ${ }^{14}$ Thus, commentators often assume that the objects of the Postulates, especially God and immortality, are the objects of Kantian hope (O'Neill 1996, Flikschuh 2009). If this was right, Kantian hope would be a form of radical or unimaginable hope, because the Postulates outstrip our conceptual abilities to comprehend them (Martin 2014: 103-104). However, as Andrew Chignell has pointed out, Kant believes that 'what may I hope?' is a question for the philosophy of religion, rather than for the critique of reason (Chignell 2013, 2014). On this reading, Kant argues that we have good reasons to believe or have faith (Glauben) in, rather than hope for, God's existence and the immortality of our soul. And it is this belief that warrants Kantian hope for God's assistance in our quest for moral perfection (Rel 171), for happiness in proportion to virtue (A809/B837; KpV 122-25), and for the establishment of an ethical community on earth (Rel 94). Thus, the Postulates themselves are not the objects of hope, because while moral belief is not knowledge, or, logical certainty, it is stronger than hope, namely, moral certainty (Chignell 2013: 198). As Kant puts it: 
The conviction is not logical but moral certainty, and, since it depends on subjective grounds (of moral disposition) I must not even say 'It is morally certain that there is a God,' etc., but rather 'I am morally certain' etc. That is, the belief in a God and another world is so interwoven with my moral disposition that I am in as little danger of ever surrendering the former as I am worried that the latter can ever be torn away from me. (A828-29/B857-58)

The purpose of the Postulates is to provide the real ground for hope and, therefore, to make Kantian hope rational hope. To see this, consider what the rational constraints on rational hope are, according to Kant. Following Chignell's reconstruction, 'S's hope that $p$ is rational only if $\mathbf{S}$ at least rationally believes that $p$ is really possible' (Chignell 2013: 209). 'Real possibility' is a technical term in Kant and refers to a possibility whose actualization has a real ground, that is, something exists which makes it possible for the possibility to be actualized. This distinguishes real possibility from mere logical possibility, which only requires that its actualization would not be contradictory. ${ }^{15}$ The upshot of this brief detour into Kant's modal metaphysics is that Kantian hope for a better, future world requires moral belief in God's existence and the immortality of the soul, because God and immortality provide the real ground for the possible actualization of the hoped-for outcomes. Belief in the Postulates of Pure Practical Reason warrants hope. Read in this light, Adorno's discussion of the Postulates should be understood as arguing that, after the Holocaust, we are no longer warranted in believing the Postulates of Pure Practical Reason to be true, and, therefore, we have no rational warrant for Kantian hope. ${ }^{16}$

Adorno's first argument against Kant's Postulates concerns the compatibility of our experiences in the actual world with any possible, better world. In particular, Adorno argues that the experience of the Holocaust forces us to re-evaluate the traditional conception of 
metaphysics, which underwrites our hope for a better future, and which he also ascribes to Kant. According to this conception of metaphysics, "the immutable is truth and the mutable, transient is semblance [Schein]', so that there is a 'mutual indifference between temporal things and eternal ideas' ( $N D$ 354/361). As a result, nothing that happens in the actual world should, in principle, undermine our belief in an ideal, transcendent order that would vouchsafe our future redemption and enable us to reconcile ourselves to our actual world. However, according to Adorno, the Holocaust has destroyed any sense that an appeal to transcendent entities can endow immanent experience with a positive meaning. It 'make[s] a mockery of the construction of immanence as endowed with meaning radiated by an affirmatively posited transcendence' (ND 354/361). Philosophers of history cannot integrate the Holocaust into a progressive historical narrative; no theodicy is possible in the postAuschwitz world. As a result, our 'ability to engage in metaphysics is paralysed because what happened shattered the basis on which speculative metaphysical thought could be reconciled with experience' (ND 354/361-62). This sentiment is often expressed in terms of the inability to believe in God after Auschwitz.

Historical-philosophical reflection turns the table on traditional conceptions of metaphysics insofar as it takes an immanent event, the Holocaust, and its consequences, inexpressible suffering, as index veri for the transcendent. 'The course of history forces materialism upon metaphysics, traditionally the direct antithesis of materialism' ( $N D$ 358/365). Adorno's Meditations bring metaphysics into a dialectical relationship with the empirical world: not only does metaphysics orient us in our empirical life, but our empirical life constrains what our metaphysics can be. This is broadly compatible with Kant, who also believes that our metaphysical commitments ultimately are motivated by moral concerns. However, Adorno thinks that after Auschwitz '[n]o word tinged from on high, not even a 
theological one, has any right unless it underwent a transformation' (ND 360/367). On this view, the Holocaust has created a sphere of pure immanence, where no appeal to transcendent ideals is possible and everything that can be thought at all is immanent in the empirical world. If this is true, then the question becomes whether 'metaphysical experience', and therefore, Kantian hope, is still possible (ND 365/372, see also my discussion in §5).

Adorno's second argument against Kant concerns the immortality of the soul, a belief that occupies a central place in Christian thought and, therefore, also in traditional metaphysics in the Western philosophical tradition. Adorno's argument parallels the argument about a future, better world. He argues that our recent historical experience has robbed us of what made death bearable in the past, namely, 'the feeling of its epic unity with the rounded [gerundeten] life' (ND 362/369). Of course, Adorno is aware of the dubious character that this solace takes when he writes that old and tired people feel that it is right for them to die because their lives were already not lived any longer in any emphatic sense. Nevertheless, in our administered society (der vergesellschafteten Gesellschaft) even that solace is absent and death has become incommensurable with life. Furthermore, Adorno suggests that our knowledge of the Holocaust deprives us of the hope of an afterlife.

Death in the camps is a new horror: since Auschwitz, fearing death means fearing worse than death. What death does to the socially condemned can be anticipated biologically on old people we love; not only their bodies but their egos [ihr Ich], everything that determined them as human, crumbles without illness or violent intervention. The remnant of confidence in their transcendent endurance vanishes during their life on earth, so to speak: what should be the part of them that is not dying? (ND 364/371) ${ }^{17}$ 
Adorno seems to say that certain forms of life make it impossible to believe in immortality, because in them people have no sense of being alive, being subjects, having worthwhile experiences even during their lives. ${ }^{18}$

Taken together, if Adorno is right, these arguments suggest that our experience of life has rendered belief in God's existence and our immortality problematic for reasons to do with our experience in the actual world. Adorno speaks of the 'historical-philosophical collapse of the metaphysical ideas' (ND 365/372), which renders them absurd. However, since the Postulates of Pure Practical Reasons provide the warrant for the rationality of Kantian hope, the demise of the Postulates also renders Kantian hope for God's assistance in our quest for moral perfection, happiness in proportion to virtue, and the establishment of an ethical community on earth irrational.

Of course, these arguments are open to objections. In particular, defenders of Kant could deny that any empirical arguments can undermine our moral beliefs in God and immortality. Kant suggests as much in the Jäsche Logic, where he argues that moral belief is a holding-tobe-true (Fürwahrhalten) 'of what I accept on moral grounds, and in such a way that I am certain that the opposite can never be proved' $(L 67) .{ }^{19}$ He even suggests that this form of 'practical conviction' can be firmer than knowledge, because with knowledge 'one still listens to opposed grounds, but not with belief, because here it does not depend on objective grounds but on the moral interest of the subject' ( $L$ 72). Adorno could reply that the devastation of moral and ethical life that made the Holocaust possible has undermined the individual moral certainty that Kant presupposes in his arguments. In particular, Adorno argues that only a minimal 'ethics of resistance' is warranted in our radically evil world (Finlayson 2002, Freyenhagen 2013), and that this minimal ethics is characterised by 
humility with regard to one's moral and ethical convictions, including one's ability to know what the right thing is, to do it, and to achieve the right outcome. While Kant suggests that moral belief in God and immortality is inextricably linked with individuals' self-image as moral agents, Adorno suggests that modern individuals have lost faith in that self-image. As a result, their sense of moral obligation may not be accompanied by a sense of being justified in believing either that they are able to do the right thing or the truth of the Postulates which underwrite belief in that ability. ${ }^{20}$

Adorno's criticism of the Postulates of Pure Practical Reason and the Kantian hope they warrant does not entail a rejection of hope tout court. Adorno does consider himself a metaphysical thinker ( $M$ 177/114), and in the 'Meditations on Metaphysics' he argues that there is a conceptual space for radical hope in Kant's critical philosophy. In the Meditation entitled 'Mundus Intelligibilis' Adorno criticises Kant's conception of the intelligible sphere for its positivity (Positivität, ND 383/391). That is to say, Adorno criticises Kant for populating the intelligible sphere with concrete transcendent possibilities, which have to be affirmed in thought (God's existence, immortality). For Adorno, on the other hand, the intelligible sphere is necessary because it shows that a different world is possible. The concept of the intelligible sphere 'would be that of something which is not, and yet is not only not' (ND 385/392), and in an important passage he sketches the reasons for this claim.

The concept of the intelligible is the self-negation of finite spirit. In spirit, what merely is becomes aware of its lack; departure from existence that has become obdurate is the origin of that in spirit in which it is different from the principle of the domination of nature in it...spirit's hostility to life would be nothing but despicable, if it did not issue in its self-reflection [Selbstbesinnung]. False is the asceticism it demands of others, good is its own. (ND 384-85/392) 
In its reflection on the intelligible, reason realises its limitations. It is merely negatively thought ( ND 384/392) as a space in which the possibility of a different world can be conceived. In conceiving such a space, reason renounces its claim to encompass the absolute, a claim Adorno attributes to the need for the domination of nature. Only this self-negation, the recognition of its finitude, which prevents reason from coming to rest, enables it to preserve a space where hope is still possible that some radical change may happen ( $N D$

398/406). ${ }^{21}$ Moreover, such self-negation negates those moments of reason, which Adorno criticises throughout his work, identity thinking, the domination of nature, and compulsive self-preservation. The recognition that there is more than this holds out the hope that everything may be different one day (I will return to this thought in $§ 5$ below). In this sense, the intelligible is as necessary for Adorno's salvation of metaphysics as it was for Kant's, but Adorno defends a form of it that is compatible with his negativism. ${ }^{22}$ And this conception of the intelligible sphere provides the conceptual space for radical hope, although, at this stage, it is not yet clear what would motivate people to hope for a better future.

\section{Hope Against Reason?}

As we have seen, Adorno characterises Kant's rescue of metaphysics as 'hope against reason', motivated by the 'unthinkability of despair' (ND 378/385), and his criticism of the Postulates of Pure Practical Reason suggests that it is no longer rational to believe in God's existence or in the immortality of the soul. However, while Kantian hope is subject to rationality constraints that makes it conditional upon belief in the Postulates, radical hope is not subject to the same constraints. Due to the unimaginable character of its objects, radical hope is 'immune to empirical disappointment' (Martin 2014: 101) brought about by 
individual experience and collective history. At the same time, hope in all its forms is not a purely active, voluntary element of our rational agency. It is not something we do and can stop doing at will. Béatrice Han-Pile has argued in a recent paper that hope involves two forms of agential limitations: first, we experience the limits of our agency, because the eventuation of the hoped-for outcome is beyond our control; second, our agency also is limited, because whether we have hope for a particular outcome is beyond our control. Thus, we often feel impelled to hope in the face of adverse reasons or facts, while, conversely, when we are hopeless we cannot be talked into being hopeful through the listing of all the reasons there are for being hopeful (Han-Pile 2017: 179-84).

Adorno's own reflections on hope demonstrate its partially involuntary character. To see this, consider a remarkable exchange in Adorno's correspondence with Thomas Mann. After the publication of Adorno's In Search of Wagner, Mann sent his impressions of it to Adorno and quotes a passage from the book in which Adorno discusses the possibility that 'a degenerating [verfallende] society develops the seeds of the society that will perhaps one day take its place'. ${ }^{23}$ Mann comments: 'If there were only a single positive word, my honoured friend, that vouchsafed even the vaguest glimpse of the true society which we are forced to postulate! In this respect, and only this, your own reflections from damaged life say nothing'. ${ }^{24}$ In other words, Mann challenges Adorno to jettison his negativism and to give a positive indication of the better, future life that may be possible, a move that Adorno had ruled out in his criticism of Kant's Postulate concerning God's existence. Adorno's response is revealing:

If anything in Hegel, and in those who turned him right way up, has become part of my very flesh and blood, it is an asceticism with regard to any unmediated expression of the positive. This truly is a case of asceticism, believe me, since the opposite 
impulse, a tendency to the unfettered expression of hope, really lies much closer to my own nature. ${ }^{25}$

Adorno confesses to a psychological disposition to hope, but the reason why he refrains from expressing it is straightforwardly related to the critical aim of theory: 'I have the constant feeling that we are merely encouraging the cause of untruth if we turn prematurely to the positive and fail to persevere in the negative'. ${ }^{26}$ This renders both ordinary and Kantian hope undesirable, because they violate Adorno's negativism. He endorses a radical conception of hope that does not depend on the expression of any positive characterisation of the object of hope. However, given the partially involuntary character of hope, he still may harbour some hope, even though he refrains from expressing it.

The correspondence between Adorno and Mann contains a similar remark related to immortality. Recall that Adorno's criticism of the Postulate of the immortality of the soul is based on the idea that we can observe in old people a process of bodily and spiritual degeneration that makes it hard to believe that there is a 'part of them that is not dying' ( $N D$ 364/371). However, in a letter to Thomas Mann, Adorno describes his own experience of his mother's death in words that suggest a more complicated picture. Adorno writes:

A couple of weeks ago my mother died in New York at the age of eighty-seven. And just because our last meeting was actually so sad - I hardly recognized her any more than she recognized herself - the final parting has affected me very deeply. With a loved one we are tempted to regard even the decline that accompanies extreme old age as a merely temporary state, and we can only hope that we are ultimately right to do so. $^{27}$ 
Here Adorno seems to suggest that even when our loved ones are in terminal decline 'we can only hope' that this decline is only temporary. Of course, Adorno's comment does not contain a direct reference to immortality, and it is possible to interpret it as an expression of his hope for his mother's recuperation, but given her advanced age and Adorno's clear understanding of her condition, it seems that even this hope in some sense would be the hope to defeat mortality, and therefore hope against reason. Yet, Adorno seems to confess harbouring such hope. ${ }^{28}$

Adorno recognises, then, from his own experience, that hope is only partially voluntary. Our psychological disposition may induce us to harbour hope. He is acutely aware though that in the political realm ordinary or Kantian hope may encourage 'the cause of untruth', and, therefore, he embraces a cautious asceticism, a negativism of the imagination, with regard to any endorsement of positivity, that is, a refusal to engage in any positive expression of hope for a better future world that would render its shape more concrete. This leads us to Adorno's criticism of the metaphysical need for hope and his insistence that courage to challenge the existing world depends on knowledge of the worst.

\section{The Metaphysical Need for Hope and Knowledge of the Worst}

According to Adorno, 'in today's resurrected metaphysics need usurps what it lacks' ( $N D$ 365/372). The danger of this usurpation is wishful thinking (ND 399/407). In particular, Adorno criticizes the tendency to move from a real or imagined metaphysical need that there be hope to the conclusion that there are reasons for hope, be it ordinary or Kantian. In contrast, he believes that if there is hope, it will be radical and reveal itself to us at the moment of our full insight into our predicament, as hopeless as this may seem. Thus, hope 
comes after despair has been worked through. Any attempt to give people hope that avoids squaring up to our predicament manipulates them: 'They are treated by metaphysics in fundamentally the same way as by the culture industry' (M 195/124). Adorno develops this argument through the discussion of a conversation about Beckett that he had with his friend H.G. Adler, a Holocaust survivor and author of a well-known book on life in the concentration camp Theresienstadt. According to Adorno, Adler reacted with 'violent affect' against Beckett and said: 'If Beckett had been in a concentration camp he probably would not write these despairing things; he'd write things which gave people courage [Mut]' (M 194/124). ${ }^{29}$ And, presumably, Adler thinks that 'things that gave people courage' are hopeful things. Adorno disagrees. He sees Adler's sentiment as part of the ideological way in which metaphysical concepts are discussed at the time. They are endorsed, because people experience a need for metaphysical solace. His diagnosis of the problem is that

[T]he situations in which people are forced to think 'positively' simply in order to survive are themselves situations of compulsion, which force people back on pure self-preservation, and in thinking only what they need to in order to survive in such a situation, to a point where the truth content of what they think is hopelessly undermined and utterly destroyed. (M 194-95/124)

I think that what Adorno has in mind here is a stance of hopefulness as a psychological coping mechanism which people adopt defiantly, involuntarily or even unconsciously in order to come to terms with traumatic events, such as the Holocaust. As he sees it, if we adopt a hopeful stance out of desperation or, worse, if we are actively encouraged to be hopeful in these situations, we are manipulated and debased $(M 195 / 124){ }^{30}$ 
In Adorno's view, Beckett was lucky, not only because he was spared Adler's horrific experiences, but also because, having been spared these experiences, he was able to express truthfully the despair that he felt in the face of our predicament and thereby to serve a critical aim. This critical aim is to squarely face the worst possible truth, that is, that the Holocaust happened, and that we still live in a radically evil world, and to think it through:

If there is any way out of this hellish circle - and I would not wish to exaggerate that possibility, being well aware of the weakness and susceptibility of such consciousness - it is probably the ability of the intellect [Geist] to assimilate, to think the last extreme of horror and, in face of this intellectual [geistigen] experience, to gain mastery over it. (M 196/125, translation modified)

This kind of mastery is intellectual and emotional at once. It enables the thinker to comprehend the worst and to stand above it, in some sense. As Adorno puts it, 'in the ability not to feel manipulated, but to feel that one has gone relentlessly to the furthest extreme, there lies the only respect which is fitting: a respect for the possibility of the mind, despite everything, to raise itself however slightly above that which is' $(M$ 196/125). In this context, Adorno recalls that he and Horkheimer found reading Eugen Kogon's book, The SS-State, ‘immensely liberating' (M 195-96/125). ${ }^{31}$ Adorno makes a similar claim in Minima Moralia when he introduces the second part of that book, which collects reflections written in 1945 , with an aphorism by F.H. Bradley, which reads: 'Where everything is bad / it must be good / to know the worst' (MM 94/83). Given Adorno's well-established views on the radically evil character of the modern world and the context of delusion (Verblendungszusammenhang) which prevents us from breaking out of it, why should it be good to know the worst? 
The answer, I think, is that contrary to what Adler thought, it is exactly this process of working through and reflecting on the despair occasioned by the Holocaust that can instil courage in people which will enable them to remain critical of the wrong life and to resist it where possible. To see this, we need to understand the relationship between radical hope and courage.

According to Lear, in the most general terms, courage, as a human excellence or virtue, is 'the capacity for living well with the risks that inevitably attend human existence' (Lear 2006: 121). So understood, radical hope may be both a necessary constituent and a manifestation of courage (Lear 2006: 123). It is a necessary constituent, because courage may require the capacity to live with conceptual loss, where established structures of meaning and significance no longer apply, and radical hope is required in order to believe in the possibility of conceptual renewal. It is a manifestation of courage, if it is well deployed in order to enable the courageous person to judge well the risks of life. As Lear sees it, Plenty Coups needed radical hope in order to have the courage to lead the Crow into an unknown future, and his capacity to do so well manifested his radical hope in that future. Likewise, Adorno is concerned with the courage to live in the wake of the Holocaust, and this form of courage seems to rely on radical hope, not only for the possibility of continued living, but also for his capacity to resist the wrong life and to fight for a better one with the means of critical theory. Here, Adorno agrees with Kant: 'Without hope there is no good [Ohne Hoffnung ist kein Gutes]' (ND 272/276). ${ }^{32}$ At the same time, Adorno's courage in confronting the past, working through and reflecting on the Holocaust, manifests the radical hope that it is possible to liberate oneself from disabling despair in the face of what happened and discloses a new space of future possibility, even if it is completely indeterminate. 
At this point, we can return to the distinction between Lear's and Adorno's conceptions of radical hope. While Plenty Coups finds in the Crow past ready resources for courage and hope, for Adorno the past is a vast reservoir of devastation and human suffering. Working through the past and understanding it as fully as possible enables Adorno to move from despair to hope, because it ensures that we understand the full force of our predicament and guards against the temptation of ordinary hope. As we have seen, Adorno is aware that 'the possible' blocks the path to utopia. As long as we believe that we have enough real or imaginative resources to picture a determinate better, future world, we have not escaped the spell.

Moreover, reflection on the history of the modern world, including a detailed understanding of the processes that led to the Holocaust, enables us to see the historical specificity and contingent character of these processes. We can see that the Holocaust was neither a natural nor a necessary outcome of human history, even if the dialectic of enlightenment establishes $a$ relationship between the pathological practices of selfpreservation and the domination of nature on the one hand, and the Holocaust on the other. It is good to know the worst, here understood as the precise details of the horrors of the Holocaust, then, because this knowledge denaturalises it and therefore liberates us by opening up the possibility of an alternative future in which 'Auschwitz will not repeat itself' (ND 358/365). In this sense, the negative character of thought (in the Hegelian sense of negating what it encounters as given) is itself a possible source of hope. ${ }^{33}$

\section{Reasons for Hope}


In addition, Adorno suggests at least two further reasons for hope: (1) there is an objective possibility of addressing some of the social suffering that afflicts the world because of the development of the forces of production, and (2) some metaphysical experiences offer a promesse de bonheur, which can serve as a placeholder for a future good without itself being that good.

\section{1}

In the Introduction to Negative Dialectics, Adorno contrasts the wrong state of affairs in which we live with 'the concrete possibility' of utopia (ND 22/11). He introduces this contrast immediately following a comment about the fact that even in the most capitalist societies the focus on exchange cannot eliminate the centrality of use value for the maintenance of life. This could be understood as an allusion to Marx's claim that in such societies the relations of production become fetters on the forces of production, that is, the social organisation of production and exchange in capitalism makes impossible the full use of productive capacities which could satisfy everyone's basic needs and overcome social suffering. Elsewhere, Adorno reflects on the fact that the development of the forces of production has progressed to the point where nobody would need to suffer hunger (Adorno 1976: 62/ GS 8: 347; $C M$ 96/ GS 10.2: 564); yet, hunger persists even in wealthy capitalist societies due to the way in which production and exchange are organised. This suggests that there is a 'concrete' or 'objective' rather than merely logical possibility that some good could be brought about in our world, and this surely is a reason for hope. However, Adorno is not naïve. Such hope remains radical hope for two reasons. First, we currently cannot conceive of the concrete steps that we would need to take in order to abolish hunger in the world (and, similarly, meet everyone's other basic needs), and we do not fully understand the nature of 
the obstacles that prevent us from doing so. Second, the merely negative goal of abolishing hunger does not give us a positive image of a good society. Freyenhagen's negative Aristotelianism illustrates this claim: knowledge of the bad arises from finding out of what is bad for us qua animals (e.g. hunger), but this doesn't tell us what would be good for us qua humans. We simply do not know what forms of flourishing would open up for us in a world in which hunger has been abolished (Freyenhagen 2013: 240). Nevertheless, given the concrete or objective possibility of abolishing hunger, it seems reasonable to hope that we will achieve it in the future, and that this eventually may lead to the establishment of a better, future life that we cannot yet imagine.

\section{2}

Adorno also suggests that 'metaphysical experience' can give us reasons for hope, if we are lucky enough to have such experiences. ${ }^{34}$ To be sure, the concept of metaphysical experience is difficult to grasp, and I won't be able to do it justice here. Rather, I will sketch the general shape of the argument and refer the reader to fuller discussions in the existing secondary literature (see especially Foster 2007; Jarvis 1998: Ch. 8; Bernstein 2001: Ch. 9; Zuidervaart 2007a: Ch. 2, 2007b). Metaphysical experience of objects is experience in a manner that is not tainted by identitarian, formal or instrumental thinking. Adorno's examples include modern art works, the evocation of village names, landscapes and a character in a novel (the Duchesse de Guermantes in Proust's À la recherche du temps perdu, ND 366/373), or even a dog, wagging its tail in a concentration camp $\left(N D\right.$ 373/380). ${ }^{35}$ 
In the case of art works, the argument is that they serve as a promesse de bonheur, a promise of happiness that they contain in virtue of their essential nature as semblance (Schein) ${ }^{36}$ Modern art works, in particular, are semblances, because their appearance and meaning in virtue of which they command our attention give them a different kind of reality from the empirical objects that we use every day. The promise contained in the art work's semblance is that of non-semblance (ND 397/405). Given that modern art works are not semblances of anything actual, they are semblances of otherness as such. Thus, their semblance is 'an appearing and showing of transcendence', but not transcendence itself (Bernstein 2001: 435). ${ }^{37}$ As Finlayson puts it, works of art 'provoke the expectation of happiness, an expectation grounded in the present, but whose fulfilment lies in the future. The expectation is not just a wish, projected onto the work. It is more like a hope raised by the work itself' (Finlayson 2012: 395). On this interpretation, experiencing works of art can generate reasons for radical hope.

Metaphysical experiences elicited by village names, landscapes, fictional characters, or tail-wagging dogs are 'fugitive experiences' (Bernstein 2001: 437) whose unifying feature is the fact that they are experienced as 'absolutely and insolubly individuated', and therefore removed from the spell of identity and commensurability. Paradoxically, in this instance, it is the very 'thing-like' character of these objects, their seeming immediacy, which makes them objects of metaphysical experience:

The smallest inner-worldly traits would be of relevance to the absolute, for the micrological view cracks the shells of what, measured by the subsuming general concept, is helplessly individuated and explodes its identity, the delusion that it is a mere specimen [den Trug, es wäre bloß Exemplar]. Such thinking shows solidarity with metaphysics at the moment of its fall. (ND 400/408) 
The reconciliation that is achieved in such experiences consists in a non-instrumental and non-dominating subject-object relation that implies a critique of the existing relations between subject and object, which are instrumental and dominating. The fact that such metaphysical experience is possible can give us hope that a better, future world may be possible, too, and this hope can give us the courage we need to fight for social change.

To be sure, if substantive negativism is true, then these phenomena cannot be proper instances of the good that persist in the evil world, and even if substantive negativism was false, epistemic negativism means that they would be unrecognisable as such. To dispel the worry that metaphysical experience is incompatible with negativism, we need to spell out exactly what the relationship between metaphysical experience and the good is. Commentators like Jarvis (1998: 211-16) and Bernstein (2001: 437-51) draw on passages in which Adorno seems to concede the necessity of positive otherness being present in experience. Thus, alluding to Hegel's famous phrase, Adorno writes that 'consciousness could not even despair over the grey, did it not harbour the notion of a different colour, whose dispersed traces are not absent from the negative whole' (ND 370/377-78). The argument is conceptual; despair cannot be total, because despairing requires some nonnegative element in the world (Jarvis 1998: 212-13; Bernstein 2001: 437-8). ${ }^{38}$ However, while this argument shows that fleeting moments of happiness and of otherness can be found in our radically evil world, their entanglement with radical evil and their fugitive character mean that they cannot be conceptualised, used and reproduced in the same way as other events. In particular, Adorno does not think that the phenomena he describes are traces of the good in the sense that they could underwrite a normative ethics. Rather, they are ephemeral reminders of the possibility of non-instrumental or non-dominating relationships that offer 
hope, if they are experienced in this way. They remain promissory of future happiness and otherness (Bernstein 2001: 439).

Moreover, Adorno thinks that possession of the capacity to have metaphysical experiences of this kind itself is a matter of luck, because it depends on a particular form of upbringing that involves habituation into such experiences, and the ability to be affected by them (ND 51/41). It is not implausible, although, of course, regrettable that such metaphysical experience is not possible for everyone. In fact, what sometimes has been criticised as an anti-democratic and elitist aspect of Adorno's thought, in fact, may be the beginning of an explanation of the involuntary character of hope in those who are disposed to it. That is, it may explain why some people seem naturally hopeful in the face of adverse conditions, while others are not. And, as we have seen in $\S 3$ above, it also may be that people who are naturally hopeful find it easier to be cautiously ascetic about the expression of their hope, than those whose metaphysical need leads them to false hope. As Bernstein puts it, 'if an empirical metaphysical experience offers hope...the parading of such would undermine the strategic ethical orientation of [Adorno's] writing' (Bernstein 2001: 441).

\section{Conclusion}

In this paper, I have argued that Adorno defends a radical conception of hope. It is radical, because it is hope for a better, future world that leaves the character of this world entirely indeterminate, but holds out hope for its possibility and motivates us to resist the wrong world that we inhabit now. Adorno believes that hope must be radical in this sense, because he is committed to a negativism about the good that is epistemic and imaginative: we can neither know nor imagine the good. His conception of hope differs from ordinary hope, Kantian hope, and Lear's conception of radical hope. It does not have determinate empirical 
objects or require moral belief in transcendent objects that would warrant hope. And it does not require a belief in the essential goodness of the world, human civilisation or the past. It does require, however, that we understand and explain the radically evil world that we inhabit at the moment, because it is this activity (the explanatory-diagnostic function of critical theory) that facilitates courage and hope (the anticipatory-utopian function of critical theory). Moreover, our best efforts to know the worst are not enough. Adorno clearly recognises an involuntary element in hope. Ultimately, whether we are hopeful is not up to us, but Adorno offers the beginnings of an account of what might make a difference: there are reasons for hope, including the idea that critical thought itself may give rise to hope, hints of the 'concrete' possibility of utopia (albeit in the very limited sense described in $\$ 5.1$ above), and a particular capacity to be affected by the world through metaphysical experience. This is very different from the metaphysical framework that Plenty Coups had at his disposal, and perhaps a more appropriate explanation for the vagaries of hope for those of us who do not share Plenty Coups' or any other religious commitments.

\section{Acknowledgments}

I presented an early version of this paper at a workshop on 'The Theological Virtues in Critical Perspective', organised by the Ethics of Powerlessness Project at the University of Essex. I am grateful to Béatrice Han-Pile, Dan Watts and David Batho for inviting me to present my work there and for very detailed comments on later drafts of the paper. Many thanks also to the audience and the other participants at the workshop for stimulating discussion, and to Fabian Freyenhagen for valuable feedback and suggestions. 


\section{References}

Works cited by abbreviation

Adorno:

All references to Adorno's writings are first to T.W. Adorno, Gesammelte Schriften (GS), ed.

R. Tiedemann et al., 23 volumes (Frankfurt: Suhrkamp, 1997) and Nachgelassene Schriften

(NaS), edited by the Theodor W. Adorno Archiv (Frankfurt: Suhrkamp, 1996-) and second to the following English translations (frequently amended):

CM: Critical Models. Interventions and Catchwords, trans. Henry W. Pickford (New York: Columbia University Press, 1998).

DdA: Dialectic of Enlightenment, ed. G. Schmid Noerr, trans. E. Jephcott (Stanford: Stanford

University Press, 2002). [GS 3]

ISW: In Search of Wagner, trans. Rodney Livingstone (New York: Schocken, 1981). [GS 13]

M: Metaphysics: Concept and Problems, trans. Edmund Jephcott (Cambridge: Polity, 2000) [NaS IV.14]

MM: Minima Moralia. Reflections on a Damaged Life, trans. Edmund Jephcott (London and New York: Verso, 2005). [GS 4]

ND: Negative Dialectics, trans. E. B. Ashton (London and New York: Routledge, 1973). [GS 6]

Kant: 
All references to Kant are to the pagination of Kants Gesammelte Schriften (Ak), edited by the Deutsche (formerly Königlich Preussische) Akademie der Wissenschaften, 29 volumes (Berlin and New York: de Gruyter, 1902-) with the exception of the Critique of Pure Reason, where references are given to the first (A) and second (B) editions respectively. The following translations have been used:

A/B: Critique of Pure Reason (1781/1787), trans. and ed. P. Guyer and A. W. Wood (Cambridge: Cambridge University Press, 1998). [Ak 3+4]

KpV: Critique of Practical Reason (1788), trans. M. J. Gregor, ed. A. Reath (Cambridge: Cambridge University Press, 1996). [Ak 5]

L: Lectures on Logic, trans. and ed. J. Michael Young (Cambridge: Cambridge University Press, 1992). [Ak 9]

Rel: Religion Within the Boundaries of Mere Reason (1793), in Religion and Rational Theology (The Cambridge Edition of the Works of Immanuel Kant), trans. and ed. A. W. Wood and G. di Giovanni (Cambridge: Cambridge University Press, 1996). [Ak 6]

Other Works

Adorno T.W. and T. Mann (2006), Correspondence 1943-1955, ed. C. Gödde and T. Sprecher, trans. N. Walker. Cambridge: Polity.

Adorno, T.W. et al (1976), The Positivist Dispute in German Sociology, translated by Glyn Adey and David Frisby (London: Heinemann).

Allen, A. (2016), The End of Progress: Decolonizing the Normative Foundations of Critical Theory. New York: Columbia University Press. 
Benhabib, S. (1996), Critique, Norm, and Utopia: A Study of the Foundations of Critical Theory. New York: Columbia University Press.

Benjamin, W. ([1924-25] 1996) 'Goethe's Elective Affinities', in W. Benjamin, Selected Writings, Vol. 1, ed. M. Bullock and M.J. Jennings. Cambridge MA: Harvard University Press.

Bloch, E. (1987), The Utopian Function of Art and Literature: Selected Essays, trans. J. Zipes and F. Mecklenburg. Cambridge MA: The MIT Press.

Bloch, E. (1985), Tendenz-Latenz-Utopie. Frankfurt: Suhrkamp.

Chignell, A. (2014), 'Rational Hope, Possibility, and Divine Action', in G. Michalson (ed.), Kant's Religion within the Boundaries of Mere Reason: A Critical Guide. Cambridge: Cambridge University Press.

----- (2013), 'Rational Hope, Moral Order, and the Revolution of the Will', in E. Watkins (ed.), The Divine Order, the Human Order, and the Order of Nature: Historical Perspectives. Oxford: Oxford University Press.

Finlayson, J.G. (2012). 'The Artwork and the Promesse Du Bonheur in Adorno', European Journal of Philosophy 23(3): 392-419.

---- (2002), 'Adorno on the Ethical and the Ineffable', European Journal of Philosophy 10(1): 1-25.

Flikschuh, K. (2009), 'Hope as Prudence: Practical Faith in Kant's Political Thinking', International Yearbook of German Idealism 7: 95-117.

Foster, R. (2007), Adorno: The Recovery of Experience. Albany: State University of New York Press.

Freyenhagen, F. (2017), ‘A whole lot of Misery: Adorno’s negative Aristotelianism - Replies to Allen, Celikates, and O'Connor', European Journal of Philosophy 25(3): 861-74. 
---- (2013), Adorno's Practical Philosophy: Living Less Wrongly. Cambridge: Cambridge University Press.

Friedlander, E. (2012), Walter Benjamin: A Philosophical Portrait. Cambridge MA: Harvard University Press.

Han-Pile, B. (2017), 'Hope and Agency', Midwest Studies in Philosophy 41(1): 175-201.

Jameson, F. (1997), Late Marxism: Adorno, or, the Persistence of the Dialectic. London: Verso.

Jarvis, S. (1998), Adorno: A Critical Introduction. Cambridge: Polity.

Jütten, T. (2011), 'Verdinglichung und Freiheit', Deutsche Zeitschrift für Philosophie 59(5): 717-30.

Kogon, E. (1946), Der SS-Staat. Das System der deutschen Konzentrationslager (Munich: Alber).

Lear, J. (2006), Radical Hope. Ethics in the Face of Cultural Devastation. Cambridge MA: Harvard University Press.

Martin, A. (2014), How We Hope: A Moral Psychology. Princeton: Princeton University Press.

Macdonald, I. (2011), 'What Is, Is More than It Is': Adorno and Heidegger on the Priority of Possibility', International Journal of Philosophical Studies 19(1): 31-57.

O’Connor, B. (2017), 'Interests Without History? Some Difficulties for a Negative Aristotelianism', European Journal of Philosophy 25(3): 854-60.

O’Neill, O. (1996), 'Kant on Reason and Religion', the Tanner Lectures on Human Values, available at http://tannerlectures.utah.edu/_documents/a-to-z/o/oneill97.pdf.

Shuster, M. (2014), Autonomy After Auschwitz: Adorno, German Idealism, and Modernity. Chicago: The University of Chicago Press.

Stang, N.F. (2016), Kant's Modal Metaphysics. Oxford: Oxford University Press. 
Theunissen (1983), 'Negativität bei Adorno', in L. v. Friedeburg and J. Habermas, AdornoKonferenz 1983. Frankfurt: Suhrkamp.

Zuidervaart, Lambert (2007a), Social Philosophy After Adorno. Cambridge: Cambridge University Press.

----- (2007b), 'Metaphysics after Auschwitz: Suffering and Hope in Adorno's Negative Dialectics', in D. Burke et al. (eds), Adorno and the Need in Thinking. New Critical Essays. Toronto: University of Toronto Press.

\section{Notes}

${ }^{1}$ For exceptions see Bernstein (2001: Ch. 9) and Zuidervaart (2007a: Ch. 2; 2007b).

${ }^{2}$ Thus, Adorno's conception of radical hope may be particularly attractive to people who share Allen's scepticism about progress (Allen 2016).

${ }^{3}$ This is sometimes called the 'orthodox view' of hope (Martin 2014).

${ }^{4}$ Freyenhagen $(2013: 9,10)$ cites both of these passages in his discussion of negativism, but he doesn't distinguish imaginative negativism as a distinct form of negativism.

${ }^{5}$ Note that, according to Lear, the conception of divinity itself may change (Lear 2006: 98).

${ }^{6}$ However, it may provide us with robust negative values that would enable us to judge what such a future ought not to be like (Freyenhagen 2013).

${ }^{7}$ Similarly, Adorno writes: 'To this day, all happiness is a pledge of what has not yet been, and the belief in its imminence obstructs its becoming' (ND 346/352).

${ }^{8}$ For a similar interpretation to the one offered here, see Macdonald (2011: 40-46). 
${ }^{9}$ For example, Adorno refers to the 'utopia of cognition' as a state in which we would be able 'to open up the non-conceptual with concepts, without making it the same as them' (ND 21/10).

${ }^{10}$ Note that this is true even if substantive negativism is false. Since we cannot reliably pick out the good, we could not identify an untainted possible future if we happened to stumble upon one.

11 The three 'models' of negative dialectics that Adorno offers in the second half of the book correspond to these three propositions, although Adorno transforms their direction. The first model deals with freedom, the second deals with the philosophy of history, and, therefore, with the question of whether there is meaning and progress in history, a secular way of asking whether God has a plan for us. Finally, the third model deals with the possibility of metaphysics and metaphysical experience itself; it includes discussions of theodicy and immortality, but it also draws together the insights of the whole book and considers what we may hope, even though the discussion is not explicitly framed as a discussion of hope. For a slightly different mapping see Jameson (1997: 73-77).

The three 'models' also can be interpreted as answers to Kant's three questions: 'What can we know? What should we do? And What may we hope?' (A804-805/B832-833). On this interpretation, the first question concerns knowledge of the meaning and progress of humanity.

${ }^{12}$ In the Dialectic of Enlightenment, Adorno and Horkheimer capture this insight in a harrowing passage: 'The domination of nature draws the circle into which the Critique of Pure Reason banished thought. Kant combined the doctrine of thought's restlessly toilsome progress toward infinity with insistence on its insufficiency and eternal limitation. His judgment is an oracle. There is no being in the world that science cannot penetrate, but what can be penetrated by science is not being' (DdA 43/19-20). 
${ }^{13}$ As Shuster puts it (2014: 40-41), Adorno does take Kantian morality as an attempt to avoid the dialectic of enlightenment.

${ }^{14}$ Martin (2014: 103, note 11) acknowledges the distinction but then argues that moral faith is a specific form of hope: hope plus confidence (105).

${ }^{15}$ For more on this distinction and Kant's theory of real possibility see Stang (2016).

${ }^{16}$ As will become clear in what follows, for Adorno, hope must be based on a form of possibility that is weaker than real possibility but stronger than logical possibility See also Macdonald (2011: 45).

${ }^{17}$ It is worth noting that Adorno appeals to the process of ageing and dying in order to make a more specific point about the horrific process of dying in Auschwitz. As a result, it looks as if our ability to hope for immortality is imperilled not only by Auschwitz, but also by witnessing loved ones who suffer from the kinds of illnesses that destroy people's personalities, such as Alzheimer and other forms of Dementia. (I assume that when Adorno writes 'without illness' he means 'without physical illness, since the 'crumbling' of the ego through Alzheimer or Dementia clearly is an illness.).

${ }^{18}$ It is not clear why Adorno thinks that living an impoverished life should decrease rather than increase one's hope for immortality. Perhaps he thinks that it is difficult to imagine a better, future life if one's current life is characterized by the decline of one's powers and one cannot imagine what a better life would look like.

${ }^{19}$ In fact, '[t]he only objects that are matters of belief are those in which holding-to-betrue is necessarily free, i.e., is not determined through objective grounds of truth that are independent of the nature and the interest of the subject... Thus also on account of its merely subjective grounds, believing yields no conviction that can be communicated and that commands universal agreement, like the conviction that comes from knowledge. Only I myself can be certain of the validity and unalterability of my practical belief, and my belief in 
the truth of a proposition of the actuality of a thing is what takes the place of a cognition only in relation to me without itself being a cognition' $(L 70)$.

${ }^{20}$ For a similar conclusion see Shuster (2014: 128), who writes that 'Adorno's basic contention is that reconciliation with our present world is prohibited.' Since Adorno comes to reject the Postulates, he finds himself in a conceptual space that is very different from Kant's, but he arrives at it through reflection on the problems with Kant's conceptual space. I am grateful to an anonymous reviewer for alerting me to Shuster's framing of Adorno's point.

${ }^{21}$ Michael Theunissen has pointed to the irony of Adorno's resurrection of the intelligible sphere after all of his work in demolishing it. But I think that Adorno's conception of it is very different from Kant's in that it is entirely indeterminate (Theunissen 1983: 60).

${ }^{22}$ Like Adorno, Kant thinks that we cannot know anything about the intelligible sphere, but he does think that we can conceive of immortality and God's existence and have faith in it. Adorno seems to deny this too.

${ }^{23}$ ISW: 143/153; quoted in Mann's letter to Adorno, 30 October 1952, in Adorno and Mann (2006: 93). I have modified the translation, rendering verfallende as 'degenerating' rather than as 'decadent'.

${ }^{24}$ Letter to Adorno, 30 October 1952, in Adorno and Mann (2006: 93). 'Reflections from Damaged Life' is the subtitle of Adorno's Minima Moralia.

${ }^{25}$ Letter to Mann, 1 December 1952, in Adorno and Mann (2006: 97). Those who turned Hegel 'right way up' are Marxists.

${ }^{26}$ Ibid.

${ }^{27}$ Letter to Mann, 13 April 1952, in Adorno and Mann (2006: 78-79).

${ }^{28}$ Incidentally, Adorno seems to think that the hope for immortality occupies a special place in all utopian longing. In Negative Dialectics Adorno criticises Christianity for spiritualising resurrection: 'hope means a physical resurrection and feels defrauded of the 
best part by its spiritualization [Vergeistigung]' (ND 393/401). (This is a peculiar claim, because much Christian doctrine in fact does hold out hope for resurrection of the 'glorious body'.) It is worth noting that for Walter Benjamin, who had an immense influence on Adorno's thinking about these issues, hope for immortality is concerned with the immortality of those who are dead already, rather than the living. This is the point of the famous last line of his essay on Goethe's Elective Affinities: 'Only for the sake of the hopeless have we been given hope' (Benjamin [1924-25] 1996: 356; see also my remarks in note 38 below).

In a conversation with Ernst Bloch, Adorno also suggests that the concept of utopia has a contradictory relationship to death. On the one hand, "without the notion of an unfettered life, freed from death, the idea of utopia, the idea of the utopia, cannot even be thought at all' (quoted in Bloch 1987: 10). On the other hand, death, as limit (Schwelle), must be thought as well for utopia to be possible. And Adorno concludes from this contradiction that 'one may not cast a picture of utopia in a positive manner' (quoted in Bloch 1987: 10), presumably because it is not possible to comprehend something that is contradictory. This explains why the hope for immortality is radical hope, and is much weaker than the moral belief or faith in immortality that Kant thought warranted.

${ }^{29}$ In Negative Dialectics Adorno summarises the exchange slightly differently: 'if he had been in Auschwitz, he would write differently, namely, with the trench religion [Schützengrabenreligion] of an escapee, more positively' (ND 360/367).

${ }^{30}$ This view is compatible with the view that hope is not entirely voluntary, because the manipulation that Adorno has in mind could work by creating an environment in which (false) hope is likely to flourish.

${ }^{31}$ Kogon's book, Der SS-Staat, published in 1946, is one of the first historical analyses of the Nazi system. 
${ }^{32}$ Of course, this only renders hope a necessary condition of possibility for the good, not a sufficient one.

33 For the related idea that criticism of reification, that is, the denaturalisation of seemingly natural social phenomena, already is an element of freedom, see Jütten (2011).

${ }^{34}$ I will return to this qualification below.

${ }^{35}$ Foster (2007) is very good at explaining why any such break-outs of identity thinking will be ephemeral rather than more permanent, and, therefore, why they can be found in Proust but not in e.g. Husserl, Bergson or McDowell.

${ }^{36}$ I take both the idea that art works serve as a promesse de bonheur and that they do so in virtue of their essential nature as semblance from Bernstein (2001: 435-37). For an excellent discussion of Adorno's use of the phrase promesse de bonheur, see Finlayson (2012).

${ }^{37}$ The idea that semblance gives rise to hope, even though it is semblance rather than the reality of what it resembles (e.g. reconciliation) is central to Benjamin's interpretation of Goethe's Elective Affinities (Benjamin [1924-25] 1996: 355; cf. Friedlander 2012: 211).

38 In this context, Adorno quotes Benjamin's famous conclusion from the Elective Affinities essay: 'Only for the sake of the hopeless have we been given hope' (ND 371/378; cf. Benjamin [1924-25] 1996: 356 and my remarks in note 28 above). The thought may be that reflection on past suffering gives rise to the idea of messianic justice in which that suffering still could be undone or at least be remembered in a way that affords closure. Hope is given to us, but it is for the sake of those who suffered in the past. It is because we cannot accept the finality of that suffering that despair cannot be total. This argument, which differs from the one I discuss in the main text, requires extensive metaphysical commitments that sound more Benjaminian than Adornian to me. 